DRAFT VERSION

\title{
Online content control, memory, and community isolation
}

\author{
Artur Matos Alves
}

Acknowledgments: The author would like to acknowledge the representatives of the Precários Inflexíveis association for their answers to queries.

The construction of the online presence of communities received much scholarly attention during the last two decades. The perception of an intensification of mediated sociability, as opposed to direct interaction, along with the rise of online protest and alternative community, posed interesting challenges to social and human sciences. Early studies pursued the issue of the changes in contemporary concepts of community and the role of communication technologies (among others, Donk et al., 2004; Earl and Kimport, 2011; Hands, 2011; Hick et al., 2000; McCaughey and Ayers, 2003). Digital communication networks were seen as instrumental in supporting the rise of activist communities at the national and international levels, lowering the costs of communication, expanding action repertoires, and extending reach (Bennett, 2003; Castells, 2004, 2009a; Feenberg and Bakardjieva, 2004; Flichy, 2004; Joyce, 2010a; Wellman et al., 2003).

More recently, researchers, journalists, and activists raised the alarm about the extent to which these online communities rely on a relatively narrow set of online services subject to external forms of control. They argue that the same infrastructure and services underpinning the transmission of messages, coordination or community building also allow surveillance, content filtering, censorship, and other forms of control (Deibert, 2003; Deibert et al., 2008, 2010; Greenwald, 2014; Kohl, 2012, 2013; Reporters Without Borders, 2012, 2013, 2014; Karatzogianni and Gak, 2015). Given the breadth of global surveillance, and the reach of governments in cyberspace, activist communication, and access to the public sphere are subject to sociotechnical structures of content control (DeNardis L, 2012; Elgesem, 2008; Introna and Nissenbaum, 2000; Klang, 2006; Salter, 2003).

After reviewing studies on online communities and their technological resources, this chapter will present an outline for a theoretical framework based on a phenomenological approach to the social construction of community and memory, and to the potential chilling effects caused by content controls based on legal action. The analysis draws on a defamation case against a Portuguese online community and association of precarious workers (Precários Inflexiveis) in 2011. The research addresses the following questions: how does this activist community use online resource to build and share knowledge? How do online communities face defamation claims? And how are these interventions 
affecting the role of digital networks in memory building, even as these appear to open possibilities of easy communication and remembering? This chapter makes use of transparency reports issued by Google (which include the period in question), in order to understand the relevance of defamation claims in content removal requests.

On this basis, this chapter concludes that the use of defamation claims for the purpose of controlling or eliminating content presents serious challenges to memory-building for online communities. Explicitly, there appears a risk of isolation of individuals and communities committed to social and political change, but who lack the resources to respond. It is important to establish the characteristics of the sociotechnical system and the changes it has undergone. This not only emphasizes the importance of defamation legislation for online expression, but also brings to the fore the consequences of the dependence on third party technologies for activist communities. These findings suggest a need to reassess the sociotechnological and institutional frameworks of online activism, particularly regarding the protection of fundamental rights online.

\section{Technological challenges to the missions of online communities}

Online communities may be defined as groups with shared interests and committed to a common set of values which maintain cohesion by making use of computer mediated communication tools, whether or not they exist outside the cybersphere. In this chapter, the use of the concept retains its reference to the creation of bonds outside the realm of strictly functionalistic relations. Online communities may meet offline, strengthening bonds and extending their sense of community as a result. Digital technologies also contribute to enhance communicative power in a complex global public sphere and to create publics which then intervene in support of shared political or social objectives, giving rise to what Dutton has called "the fifth estate" (2013, pp. 42-43). In this text, the concept is applied to groups of activists at the margins of the socio-economic system and dispersed, but interconnected at the symbolic and technological levels, under the logic of a globalised communication system (Castells, 2009a, 2009b). This follows Benkler's reasoning that digital networks "provide new dimensions to thicken existing social relations, while also providing new capabilities for looser and more fluid, but still meaningful social networks" (2006, p. 357).

The studies included in the book Community in the Digital Age provide a broad overview of arguments about online communities (Feenberg and Barney, 2004). Feenberg and Bakardjieva's overview of the debate includes concerns about private ownership of hardware and software sustaining the online community, arguing, in the context of a critique of 'Web 2.0' enthusiasm, for a democratically informed structuring of communitarian sociotechnological systems that avoids the mirages of technological determinism and 'cyberdemocracy' (2004, p. 22 ff.). The same case was made by Joyce, for whom, even with "the possibilities of acts of digital activism on a corporate social networking service, we certainly should continue to support the building of sustainable, long-term, noncommercial infrastructures" in order to avoid the "overwhelming 
commercialism" and its "digital cages" (2010b, p. 30). Critical authors take issue with the concept of 'online community' on the grounds that it overlooks the need for cohesive relations between members. Barney points to a continuity between the dissolution of a spatial sense of belonging to a shared lifeworld and the hopes that computer mediated communication might restore the community (2004, pp. 47-48). Sociological approaches are more inclined to admit online sociability as reinforcing communitarian bonds of affection and conducive to democratic deliberation (Etzioni, 2004).

Alternative conceptualisations of the phenomenon avoid some of the sociological connotations of the word 'community' by focusing on the role of the individual in social systems. The term 'networked individualism' signals that loose character of the social bonds in online environments and its closeness to the contemporary socioeconomic fabric (Flichy, 2004; Wellman et al., 2003), whereas the idea of a 'networkedempowered citizen' signals a participation in networks linking "online knowledge to offline practice" by sharing experiences via virtual connections for civic purposes (Coleman, 2004, p. 2).

Online activists rely, to some extent, on third-party technology to form communitarian bonds over a shared goal. Common technological infrastructure includes web applications such as blog platforms, online video and social networking services. This dependency is greater when activists lack the resources to deploy their own selfmanaged servers and applications. In fact, Joyce links the concrete infrastructure (softand hardware) adopted by the activists to their socioeconomic environment, their public, dominant societal norms and expectations, and political factors (2010b, p. 4 ff.).

Online tools can function as memory repositories for these communities. A memory repository is characterised by features which allow the conservation and construction of shared material - interactions, documents, symbols, values, and references. If online tools bring together a group with explicitly shared goals to whom the technological infrastructure provides a stable resource and meeting point, then a shared memory emerges from a history of interaction. In this sense, depending on technology, norms, and usages, digital tools may provide a relatively safe repository for common knowledge and a site for conflict resolution, policy definition, outreach, and other common activities. Hoskins refers to this use as a particular form of "mediatisation of memory" under mass and digital media, in which memory is at once more robust and "fluid", but also more easily affected by external dynamics (Hoskins 2009). Gutman et al. acknowledge the shaping of the notions of memory by the introduction of new technologies, while problematizing the role of memory in conflict (Gutman, Brown, and Sodaro 2010).

In spite of the expansion of online social activism, there is an indisputable trend for multiple instances of control to encroach upon the online public sphere. Salter argued for citizens to push back against government controls and private enclosures of online 
communities (2003, pp. 138-9). But this effort is, according to Deibert et al., becoming more difficult, as surveillance practices and data retention policies are now widespread, enforced by national and supranational entities and culminating in full censorship and blocking $(2008 ; 2010)$.

Moreover, online data is trusted to intermediaries. They are not mere carriers of information, or even product sellers, but custodians whose actions are crucial for shaping the flow of information and online discourse. "[T]heir role does not exist in a power vacuum and different national and international governance arrangements, political and corporate interests often compete for greater control over Internet intermediaries," meaning that their continued existence depends on a set of negotiated arrangements within a sociotechnological system (Mendel et al., 2012, p. 26). Intermediated sociability presents challenges to the concept of community, given the constructed, commercially instrumentalised character of the interactions, something that moreover tends to be overlooked in everyday life and naturalized in public discourse (Couldry, 2014, pp. 12-13). Norms and laws constrain the technological politics of intermediaries and other actors. Cross border online politics are catching up with online activists, as states and international governance agreements regulate activity in cyberspace without adequate answers to the challenges of protecting privacy and personal data (Mendel et al., 2012, p. 28). The adoption of practices that range from data retention policies to IP blocking is widespread, and can be linked to the intermediary position of online service providers (OSP). As Ethan Zuckerman states, the dependency on ISP means that they are in a unique position to censor or control content (Zuckerman, 2010, p. 71). ${ }^{\text {i }}$

While in non-democratic societies content control is repressive and entails a mix of censorship, blocking, or filtering, "in democratic societies, issues of copyright infringement, hate speech, defamation, privacy protection, and child protection are at times a basis for Internet filtering or other content control" (Dutton et al., 2011, p. 42). Content control, understood as the imposition of limits to published materials, may be a legitimate option for balancing rights. However, when taken to an extreme, it negatively impacts democratic practices.

In this regard, one of the main issues highlighted in literature is how freedom of speech is to be managed online. Blogs, particularly in the case of proprietary platforms such as Blogger (Google) or Wordpress, are easy, ready to use tools for online expression, factors which have allowed their use as tools for expression, both for individuals and as fora or bases of community-building (Nardi et al., 2004). Such widely available online tools have been commonly hailed as assisting freedom of expression,, even while conceding that they are not immune to serious threats. Kahn and Kellner brought attention to blogs (including Google blogs) as activist tools, highlighting the emerging problem of blogger persecution and proposing the development of independent tools as counter, in light of the commercial character of many platforms (2004; Kahn and Kellner, 2004). 
Compared to institutional journalistic venues like news media, blogs and other 'social media' are less robust in navigating the legal and other challenges of public speech, and even journalist bloggers face 'chilling effects' that often go unnoticed (Townend, 2014, pp. 5-6). Blogs belong in a new "ecology of freedom of expression" (Dutton et al., 2011 , p. 24) but, depending on the context in which they operate, their relative novelty exposes them to multiple issues: threats, persecution, violations of privacy and personal data, libel accusations, cyberattacks, among others. Defamation actions are common, both for cases of misuse of online venues for harassment and smearing campaigns, and in attempts to intimidate and challenge bloggers (Greenslade, 2014 describes the situation in the UK after a new libel law was passed in 2013). Legal action against bloggers and blog commenters, and the elusive frontiers between editorial work, hosting, and content moderation, often present deterrents for bloggers to counter undue challenges to freedom of speech, a phenomenon which is at the heart of concerns of legal scholars debating the issue of 'chilling effects' (Abah, 2008; Berkley D. Sells, 2006; Chan, 2013; Liebman, 2006). Defamation has the potential to "have a seriously negative impact on freedom of expression," if the new online reality is not taken into account (Mendel, 2011, p. 22).

In sum, online communities present features of semi-public spheres of knowledgesharing, mutual support, memory-building, and of resistance. They are subject both to the availability of resources and online services, and to the limitations imposed by the normative contexts in which they exist. Commercial services enforce a number of conditions which are not always favourable to the expression of online activists, particularly in countries where human rights of expression and privacy are not protected. Additionally, existing legal frameworks pose challenges for online discourse, as in the case of the delicate balancing of expression and public image in defamation laws. In a dynamic sociotechnological system, authorship, archival, data retention, publication, censorship, and reporting, require extreme care to ensure a pluralistic access to democratic public spheres. Currently, intermediary or archival self-regulation exhibit great disparities of interpretation and use of laws and rights, which contributes to difficulties in the formation of alternative worldviews via online community and memory building.

\section{Technology, norms, and social interaction as features of community and memory}

This section will build on the previous review, proposing a theoretical perspective based on the phenomenological philosophy of technology of Don Ihde. This chapter builds on Ihde's concept of embodiment relations by positing that a unified entity or group may be created through a specific relation with a mediating technology, which creates a structured lifeworld open to experience. Computer-mediated communication is herein taken as an example of type of technology enabling embodiment relations, allowing the user to extend and amplify her cognitive reach. Online communities, as will be argued, depend on this constitutive embodiment relation, and require an open and pluralistic sociotechnological system for its positive contributions and demands to reach wider audiences. 
Technologies play a part in the way human beings create knowledge and culture, and communication technologies give this contribution a high degree of salience.

Technological mediation is constitutive of our experience, that is, it makes it possible to access facts and ideas in the world that would be too distant or otherwise inaccessible (Ihde, 1990, pp. 72-78). In an embodiment relation this mediating constitution of experience occurs through the double amplification/reduction of what can be experienced. An embodiment relation is not merely constitutive, or integrative. While opening up possibilities of thought and action, it also excludes, or diminishes, other options, much like a microscope amplifies a small area at the cost of obscuring everything else.

Arguing that technologies are constitutive of experience by building a shared lifeworld is not to say that they are the only factors affecting online community building. In any sociotechnical system, the shaping of the lifeworld is an articulation of norms, technologies and human elements. The first order comprises law, technical norms or standards, or habits that regulate the human and technological orders. The technological order, in brief, comprises physical objects as well as modes of production or assemblage being deployed. Lastly, the human order comprises human beings (either individually or in groups) using and shaping norms and technologies. In each of these complex and problematic orders there are elements exerting internal and external influence, and all are subject to constant changes. This tripartite system establishes a network of forces influencing each other. A change in one of those suffices to alter the form of that lifeworld, thereby demanding a new understanding of the relations between elements.

Thus, it is not only possible to speak of a shared lifeworld constructed and maintained through online communication tools, but also of a set of particular challenges posed by the structuring of such a sociotechnological system. The lifeworld is shaped by the experience of an online community built with the co-presence of individuals around shared resources. By accessing and contributing to the online community memory (blogging, messaging, commenting, emailing), the social body of the community emerges first as loose, then in the more concrete form of a network operating in turn of shared goals and references. This provides a shared vocabulary, organisation, and sets of virtual or real references which, in turn, allow a mutually significant experience of the world in the wider context. The transposition to the offline world of online relations, for example, both maintains the bonds and strengthens a communitarian lifeworld through mutual recognition. Even though the 'world' is built upon a mediated form of interaction, and often subject to the limitations of intermediation, it gives rise to a new social entity with its own identity, embedded in its context, and often - in the case of activist communities - committed to a transformative intervention therein.

The difficulties in maintaining a structured interaction are part of the embodiment relations that allow the creation of an online community. In this sense, online communities have to face the challenges posed by the intersection of their shared lifeworld and society at large. Aside from the problem of dislocation from physical 
interaction, as we have seen, communities formed around mediating technologies face connectivity issues, formal and informal normative constraints, and cohesiveness problems. ${ }^{\text {ii }}$ As suggested by some of the authors reviewed in the previous section, even a 'thin community,' connected by temporary, fluid links requires a common discursive space. Once the infrastructural conditions are satisfied, it is possible to speak of an experimental field wherein the construction of a common worldview may take place through sharing, empathy, and memory, thus avoiding essentialist notions of 'community' as constituted around stable identities and institutions (Costello, 2014, p. 12). In this sense, the technologically-mediated community is given a networked body in its interaction - simultaneously subject to the constraints of connectivity or ownership of its infrastructure, and to the norms to which a social body is bound.

In short, this analysis of computer-mediated communities takes into account how the plurality of goals, technological infrastructure, composition, and social context provide the background for the construction of a worldview. This worldview, in turn, affects the community's presence outside the boundaries of its original sociotechnological system and how it may develop its mission or achieve its goals. The possibility for action and change, then, hinges on the ability to navigate the conditions of their lifeworld, and on the extent to which alternative worldviews may reach a wider sphere.

\section{"Stop that commenter!" - the case of Precários Inflexíveis}

This analysis of some of the effects of content control upon community building rests on the study of a case involving a weblog maintained by a small Portuguese association of precarious workers. This study relies on the analysis of documents related to the case of a lawsuit for defamation filed against the association by a company and the consequences, both online and offline, of the following legal decisions. The elements on this case comprise court records made available by the association, press releases, media reports, and communications between the author and representatives of the Precários Inflexiveis association.

In order to ascertain how widespread such practices are, this chapter makes use of data made available by Google through its Transparency Reports (from 2009 to 2014). Google Transparency Reports (GTR) include data about content removal requests, user data requests, and other information related to Google's online services (Blogger, YouTube, web search, and others). Since the reports explicitly state the grounds for removal of content, this data is invaluable for insights into the current state and trends of content control in one of the main online service providers.

This section gives an account of a well-known case in which a company brought a lawsuit for defamation based on the content of anonymous comments on the blog of the Portuguese association of precarious workers Precários Inflexíveis, which was hosted in Google's Blogger platform. After describing the case, the phenomenon of online 
defamation claims and content control by OSP will be outline with Google

Transparency Reports pertaining to the years 2009 through 2014.

\section{Precarious workers, blog comments, and defamation claims}

"Precários Inflexíveis" iii is an independent association which, according to their manifesto and mission statement, proposes to advance and "defend the rights of precarious workers ... [and] strive for the end of precarious labour and worker exploitation" (Precários Inflexíveis, n.d.). In general, the PI seeks an alternative to the traditional representational structures - political parties and trade unions - in order to achieve more just labour relations for the 'precariat.' Through their website (originally a weblog on the Google Blogger platform, now moved to a new domain and format in www.precarios.net), they offer information and support to precarious workers, and have a visible presence in online and offline media. Significantly, they also provide one of the few spaces where workers can share their experiences with employers' misconduct and abuse of labour laws, usually in narratives of gross exploitation of precarious labour in the private and public sectors. This is done in a "Testimonies" section where the association publishes stories submitted by workers, followed by an open commentary section (Precários Inflexíveis, 2013). Even though the main activity of the "Precários Inflexíveis" is not whistleblowing, the "Testimonies" section contains stories (often commented by readers) of misleading job postings, employer exploitation, and other aspects of the lifeworld of precarious workers which, as seen in the previous section, represents a crucial aspect of the construction of the mediated community. Because companies are named, job seekers looking to know more about prospective employers can easily find the page in search engines, and contribute with their own comments and stories - their testimonies being, for the most part, also anonymous. The PI see these materials as part of an outreach strategy which "allows sharing ideas" and denouncing employment fraud for the benefit of the workers, to "exert pressure upon employers in order to get them to adopt better practices," and also to collaborate with the authorities (Ricardo Vicente, personal communication, December 1, 2014).

It was in the "Testimonies" section that, in May 2011, PI published a report from a former employee of a multinational company, recounting a story of wrongdoing, exploitation, gross violation of labour laws and lack of payment (Precários Inflexíveis, 2011). This report was accompanied by hundreds of comments (407, by 7 November 2012), some of which written by former employees of the same company. The comments reproduced the content of emails and letters sent by the company to applicants, detailing the job conditions, and personal narratives of the company's behaviour contradicting the job offer details. In other comments, job seekers explain how, upon searching the web for the company's name, they found the PI testimonial section, and thereupon decided to confront the company with the information, or not to go to job interviews. Other contributors still indicated that the company had changed names but maintained their recruiting practices (Precários Inflexíveis, 2011). 
Upon learning about the effects of the reports on the PI weblog, the company (or the several companies represented) asked, in August 2011, for the weblog administrator to remove the comments (more than 360 at the time), which had no effect. The company then pursued a restraining order (providência cautelar) in civil courts, seeking to make negative comments inaccessible (and not outright delete them), as well as reparations for damages to the reputation. The company's representatives argued that the contents of the weblog, and specifically the comments, made it substantially more difficult for them to hire new collaborators, causing financial and reputation losses.

The legal aspect of the case illustrates the complex landscape of online speech. Portuguese press laws ${ }^{\text {iv }}$ allow professional media the democratic freedom to publish the piece and then grant the right of reply in the same terms to the offended part, even if it is still possible to seek reparation for moral and reputation damages, according to criminal and civil law, either from the journalist or from the media company. These offenses fall under the chapter of "crimes against honour" of the Portuguese Criminal Code, the subject of "offences to reputation or good name" in the Civil Code, and are linked to the Portuguese Constitution's protection of personal reputation and good name. ${ }^{\mathrm{v}}$

The situation is somewhat different with online, non-professional media, as they neither fall under the jurisdiction of the press or libel laws, nor do they usually have the clout to retain legal help to ensure the resources needed for an often protracted legal battle in the Portuguese courts (entailing multiple stages and appeals). Thus, online publications, such as weblogs, can be directly ordered, under charges of defamation (honour crime), to remove the content, under penalty (or threat) of the country's criminal and civil laws. Furthermore, as in professional media, the fact that the publishing occurs over channels that facilitate wide circulation of content is considered an aggravating circumstance, thereby increasing the value of monetary reparation or the duration of incarceration. ${ }^{\mathrm{vi}}$ Portuguese law has in place checks and attenuating circumstances that allow the publisher to explain his actions and prove the accusations. The court may also decide that the facts reported do not warrant criminal penalties.

In the case at hand, the court accepted the request, but the decision was overturned on appeal (Faria, 2012; Soares, 2012). One of the arguments for the overturning the decision was the lack of a practical solution for deactivating or hiding the existing commentaries in that particular testimonial section without disabling commenting altogether, or otherwise deleting comments. According to the association's representatives, commenting was temporarily suspended but the testimonials' section kept publishing relevant information, while members with law specialisations defended the association in the courts (Ricardo Vicente, personal communication, December 1, 2014). The appeals court acknowledged the public interest of the contents, and did not find any evidence of losses to the company (Soares, 2012). However, the association still faced the problem of justice fees, and a civil law suit seeking EUR 60,000 in reparations. 
This was not the only attempt to remove content or shut down the PI weblog, which was taken offline by Google in November 2012 after being reported as engaging in defamation, by another company which had been the object of another "Testimonial" (European Digital Rights, 2012; Martins, 2012). After the incident, the PI blog reopened, but the contents were moved to the current website, which no longer depends on Google's services (Precários Inflexíveis, 2012). The association also procured private information security services (Ricardo Vicente, personal communication, December 1, 2014).

This description illustrates the complex nexus of online politics and the potential difficulties of activist communities in creating a community sharing experiences, as well as a drive for change. The relevance of the comments in the sociotechnological ensemble described above, and particularly in the judicial action against the PI representatives, is significant for the purpose of this chapter, and shall be examined further in the next section.

\section{Intermediation and content control in the Google Transparency Reports}

Concerning the use of legal (court and executive requests) and platform-related (flagging and reporting) tools to make removal requests, typically the former is documented, in Google's case, with the periodic Google Transparency Reports (GTR), where the company reveals requests for removal of content. ${ }^{\text {vii }}$

As incomplete as GTR remain, they provide interesting glimpses into the current state of internet politics when it interfaces with common law. A portion of content removal requests concerns copyright issues. ${ }^{\text {vii }}$ Defamation, though hard to define and framed in very different ways around the globe, is given as a motive for $24 \%$ of all removal requests for Google platforms, according to the latest available data of GTR (Graph 1 Reasons for Content Removal Requests, as Percentage of Worldwide (July 2009- July 2013). Source: Google Transparency Report). This information is in line with reports of the complex issues involving defamation lawsuits in social media (Greenslade, 2014; UNESCO, 2014, p. 28 ff.), and shows how prevalent defamation claims are in these orders, with privacy and security in second place (19\%). Hate speech, on the other hand, is much less prevalent $(4 \%)$, as are adult content $(5 \%)$ and violence $(4 \%)$. 


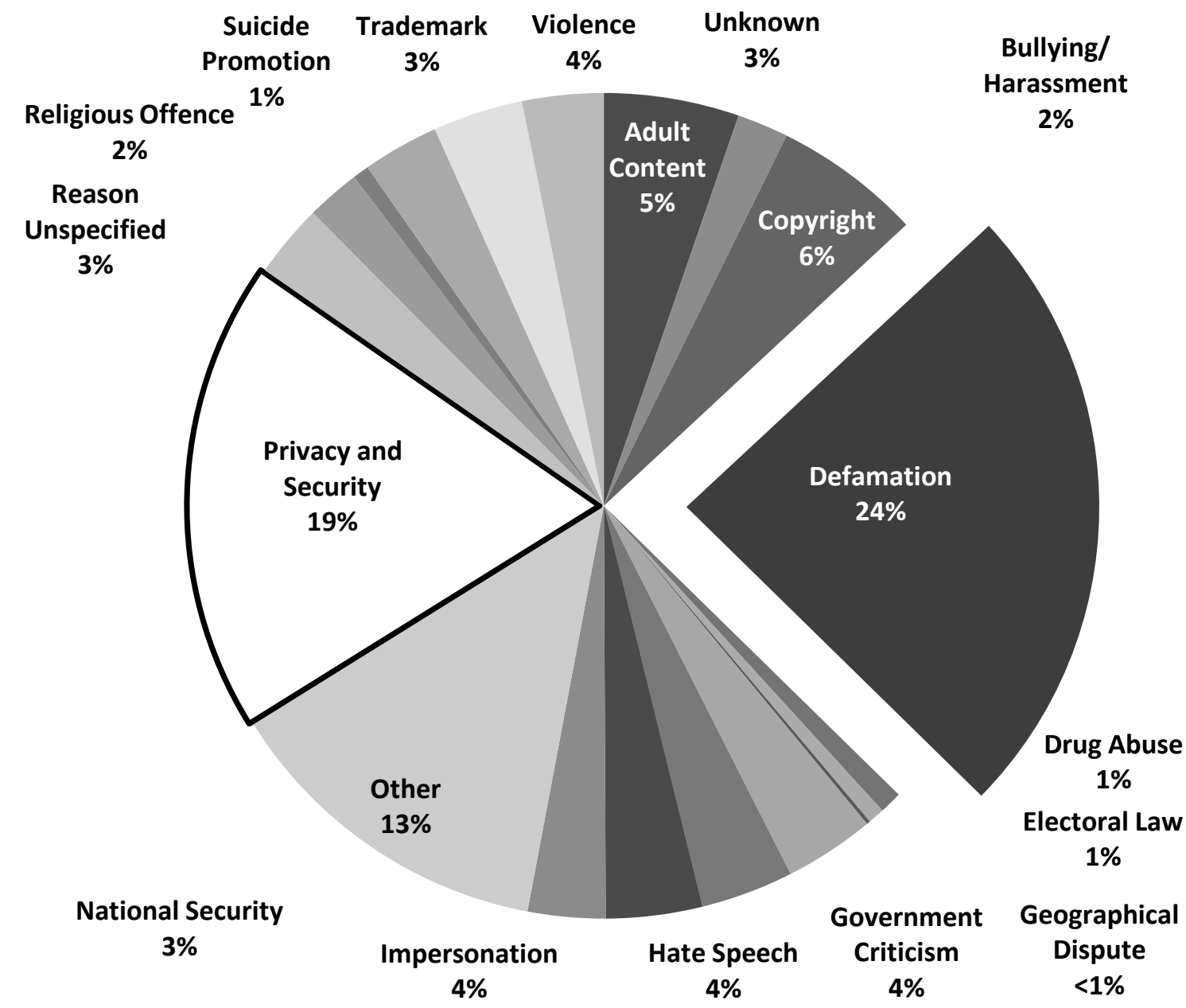

Graph 1 -Reasons for Content Removal Requests, as Percentage of Worldwide (July 2009- July 2013). Source: Google Transparency Report

It is also clear that online defamation is the reason for most removal requests from Portugal (Table 1 - Portugal: Number of occurrences of Content Removal Requests, by reason, period and Google service (January 2011 - June 2013).Source: Google Transparency Report). The table shows how many times Google was asked to remove content by the competent Portuguese authorities. These requests can be ascribed to the Portuguese legal provisions discussed earlier. Between 2011 and the end of 2013 defamationrelated requests represented 16 out of 22 occurrences ( 6 of which in 2011, the year of the case described above) The number of items requested to be removed for defamation was 51, out of a total of 61 . Most of the orders and items removed pertained to Google's blogging platform (23).

\begin{tabular}{clll}
\hline & Court Orders & $\begin{array}{l}\text { Executive, } \\
\text { Police, etc. }\end{array}$ & $\begin{array}{l}\text { Items Requested To } \\
\text { Be Removed }\end{array}$ \\
\hline Defamation & $\mathbf{1 3}$ & $\mathbf{3}$ & $\mathbf{5 1}$ \\
Blogger & $\mathbf{1 0}$ & $\mathbf{2}$ & $\mathbf{2 3}$ \\
\hline
\end{tabular}




\begin{tabular}{|c|c|c|c|}
\hline 2011 & 6 & 0 & 13 \\
\hline 2012 & 3 & 1 & 8 \\
\hline 2013 & 1 & 1 & 2 \\
\hline Google Images & 1 & $\mathbf{0}$ & 25 \\
\hline 2013 & 1 & 0 & 25 \\
\hline Web Search & 2 & $\mathbf{0}$ & 2 \\
\hline 2012 & 1 & 0 & 1 \\
\hline 2013 & 1 & 0 & 1 \\
\hline YouTube & $\mathbf{0}$ & 1 & 1 \\
\hline 2011 & 0 & 1 & 1 \\
\hline $\begin{array}{l}\text { Privacy and } \\
\text { Security }\end{array}$ & 0 & 2 & 3 \\
\hline Blogger & $\mathbf{0}$ & 1 & 1 \\
\hline 2013 & 0 & 1 & 1 \\
\hline YouTube & $\mathbf{0}$ & 1 & 2 \\
\hline 2011 & 0 & 1 & 2 \\
\hline $\begin{array}{l}\text { Reason } \\
\text { Unspecified }\end{array}$ & 1 & 1 & 4 \\
\hline Blogger & 1 & $\mathbf{0}$ & 3 \\
\hline 2012 & 1 & 0 & 3 \\
\hline YouTube & 0 & 1 & 1 \\
\hline 2013 & 0 & 1 & 1 \\
\hline Other & 2 & $\mathbf{0}$ & 3 \\
\hline Blogger & 1 & $\mathbf{0}$ & 2 \\
\hline 2011 & 1 & 0 & 2 \\
\hline Web Search & 1 & $\mathbf{0}$ & 1 \\
\hline 2012 & 1 & 0 & 1 \\
\hline Total & 16 & 6 & 61 \\
\hline
\end{tabular}

Table 1 - Portugal: Number of occurrences of Content Removal Requests, by reason, period and Google service (January 2011 - June 2013).Source: Google Transparency Report

The requests are examined by Google and thus, as the next graph shows, compliance with removal requests is not automatic. Information is provided if Google considers the request legitimate and acceptable. Therefore, a lower percentage may indicate that the requesting authorities do not have legitimate grounds on which to request user data, something that may arise from causes that range from poorly elaborated requests to economic diplomacy choices on the part of Google, who has sufficient clout to assert users' rights, particularly under coercive terms. ${ }^{\text {ix }}$ It is to be expected that compliance rates grow as authorities become more familiar with the process. In the data available by the end of 2014, the global average compliance rate is $44.6 \%$. For Portugal the rate is $36.75 \%$ (highlighted) for the period of available data (the average was $40.6 \%$ between 2009 and 2012), contrasting with $93 \%$ for Finland, $86 \%$ for the USA (93.3\% between 2009 and 2012) or $67.63 \%$ for the UK. 


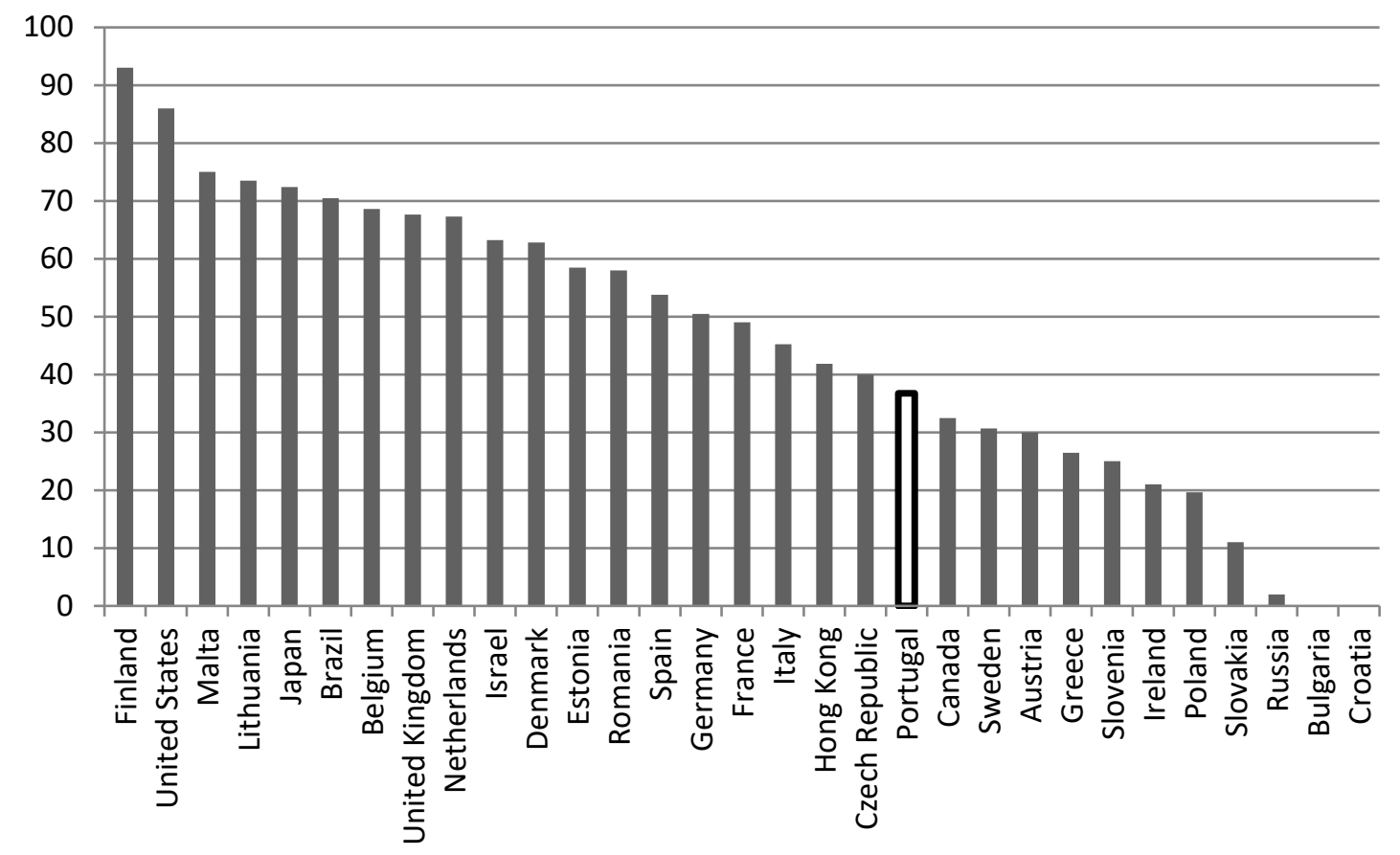

Graph 2 - Average compliance percentage for user data requests by country (31 countries shown). Global average is 44.6\%. (July 2009 - July 2014). Source: Google Transparency Report

Content removal requests are but one aspect of the interaction between the platforms and the national authorities. Graph 3 - Portugal: Evolution of User Data Requests, and Users or Accounts specified in Government requests (July 2009-June 2014). Source: Google Transparency Report shows the evolution of requests made to provide information about users, as well as the number of user accounts specified in those requests in Portugal. The growth in the number user data requests is clear, and does not show signs of levelling off. Whereas worldwide requests tripled in the 5-year period and reached a record 31,698 in the first semester of 2014 (Graph 4- Worldwide: Evolution of User Data Requests, and Users or Accounts specified in Government requests, in thousands of requests (July 2009-June 2014). Source: Google Transparency Report), in Portugal the number of requests for user data increased more than seven times. This may indicate a greater awareness of legal authorities towards online activity, and more complaints as more users become aware of negative impacts on their public image. The data provided does not allow for speculation about the nature of the requests - it shows, however, that Google, as a law-abiding multinational corporation, is under the obligation to cooperate with legal authorities, provided the requests have sufficient grounds. 


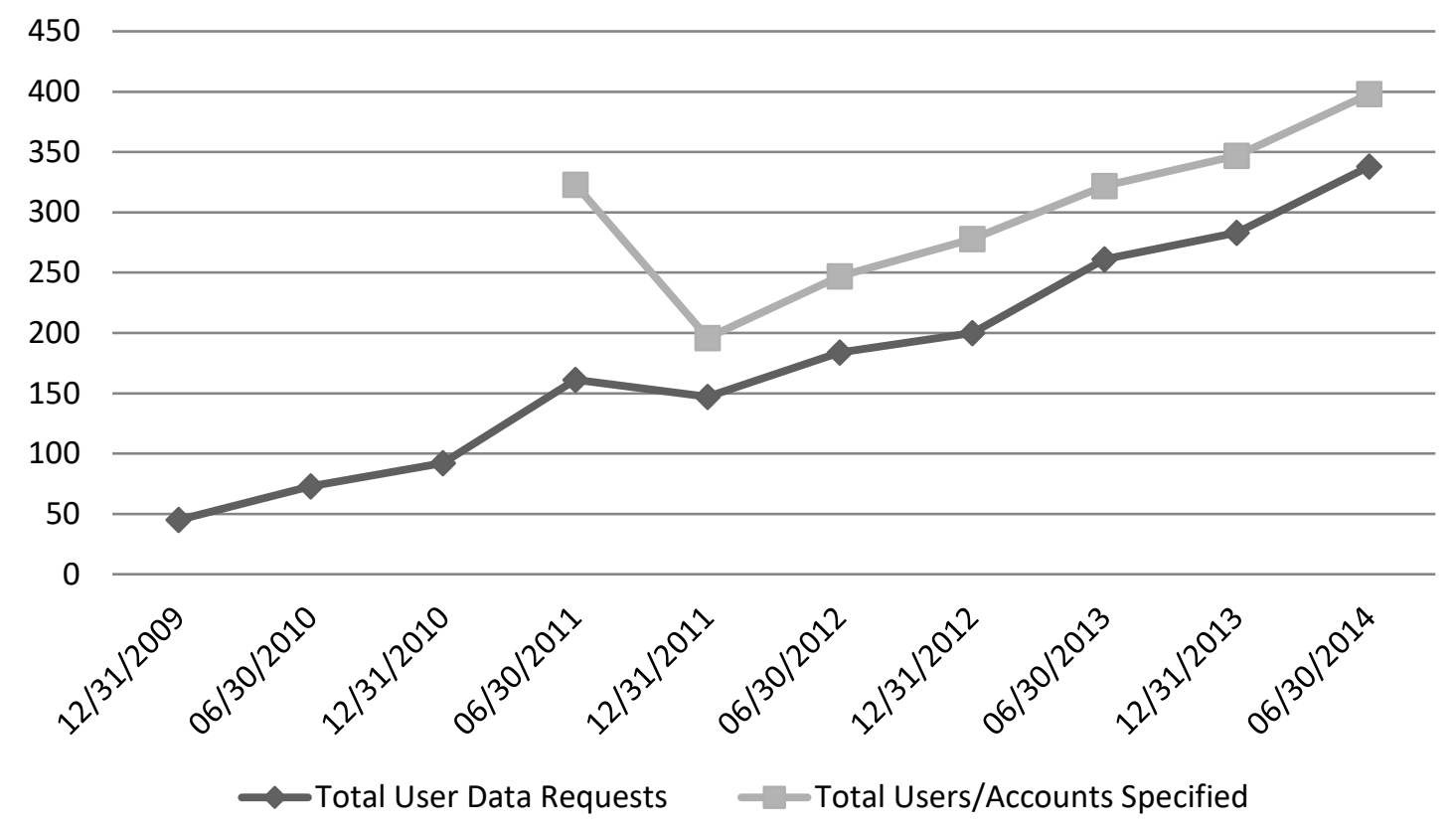

Graph 3 - Portugal: Evolution of User Data Requests, and Users or Accounts specified in Government requests (July 2009-June 2014). Source: Google Transparency Report

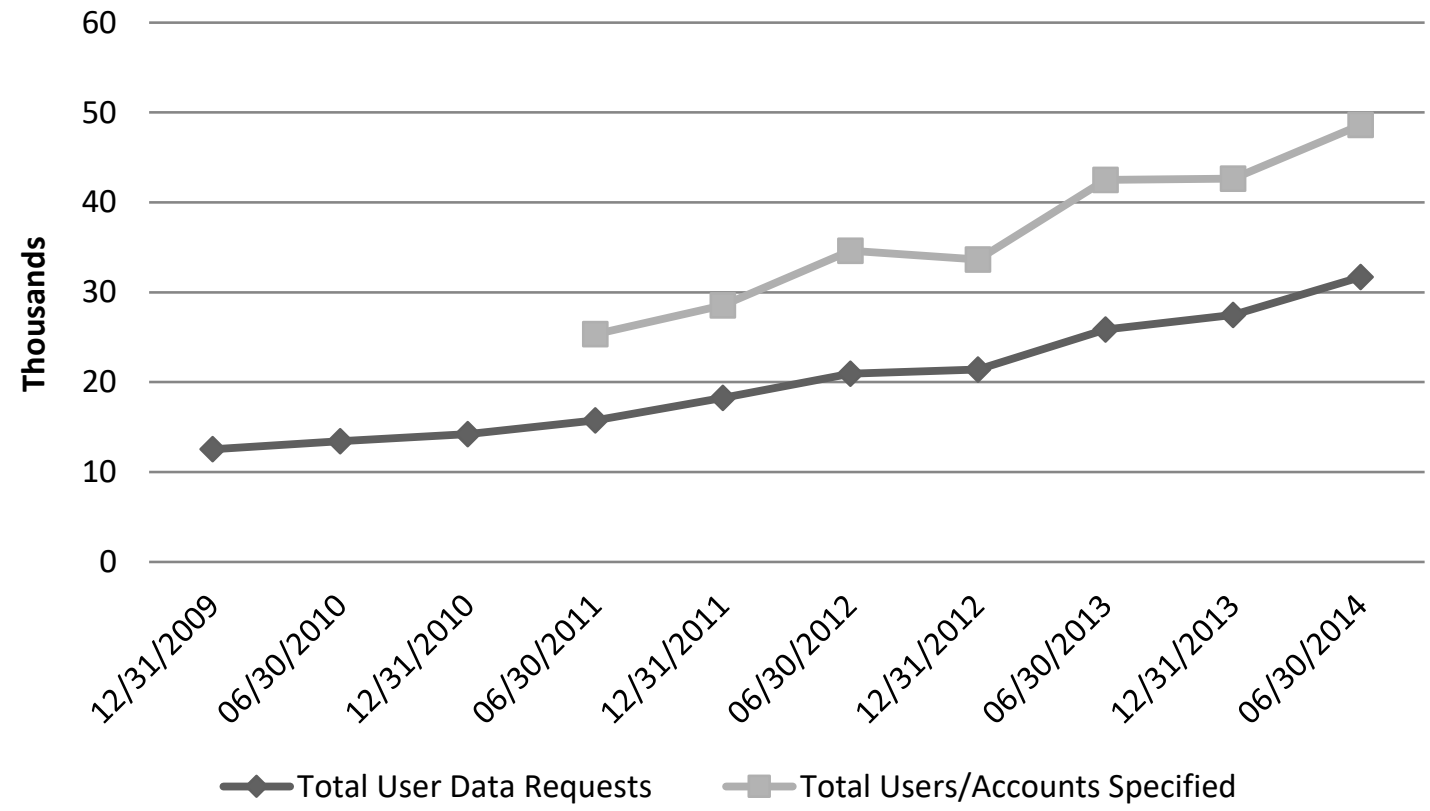

Graph 4- Worldwide: Evolution of User Data Requests, and Users or Accounts specified in Government requests, in thousands of requests (July 2009-June 2014). Source: Google Transparency Report 


\section{The interplay of memory, community and technology: constructing and communicating a worldview}

In the case presented in this chapter, the company's decision to file a lawsuit for defamation aimed to erase, or hide, the content of conversations and opinions circulating in cyberspace. When misused, these strategies may lead to excessive constraints to the connected lifeworld of activists and social movements, having dissuasive effects on the regular activities of the community, or a chilling effect. This may result in the further isolation or marginalization of communities which are committed, both online and offline, to a program of social change and the promotion of democratic or human rights. This aspect of the case can be placed in the wider context of a symbolic transformation of cyberspace into a space of conflicts and threats, in which no user is completely safe or anonymous. An UNESCO report recently signalled the particular effects of defamation laws as a form of 'legal terrorism,' pointing to "the increasing use of civil defamation, often in lieu of criminal cases, resulting in disproportionate fines and damages, particularly against media and journalists critical of governments" (2014, p. 29). It continues by specifying that 'libel tourism' has enabled powerful individuals to limit critical and dissenting voices by 'shopping' around the world for the jurisdictions most likely to approve their defamation suits"(idem). The same report also highlighted the role of online intermediaries in "preventive censorship," by pre-filtering potentially troublesome content and, in processes of "privatized censorship," by complying with governments and courts in enforcing constraining orders and legislation (UNESCO, 2014, p. 33).

One of the immediate effects, when the measures do not threaten the existence of the online communities, is the adoption of different methods, more attentive to privacy and security weaknesses hitherto unnoticed. Undeniably, then, the technologies shape the behaviour of activists and transform the community's memory - in this case, peerproduced memory, either in more the more institutional journalistic community, or in a social movement of the 'precariat'. In the "Precários Inflexíveis" case, we may witness an example of community building around shared experiences of labour exploitation and corporate backlash - a worldview which, in turn, expresses a commitment to wider changes. According to Standing, the 'precariat' is a growing class of people in multiple occupations and sector who lack "labour-related security," namely in the form of labour market, employment, job, work, skill reproduction, income, and representation security (Standing, 2011, p. 10). Calling for a new agency for the precariat is, therefore, tantamount to arguing for a way of bringing the atomised contemporary workforce together into associations or other instances that might allow them a place and a voice in the public sphere (Standing, 2011, pp. 167-168).

The sociotechnological context of the PI illustrates how online memory building depends on a degree of freedom of expression that is not limited to sharing experiences and exchanging opinions, but also entails building on that experience in order to achieve a form of cohesiveness towards action. In other words, the construction of the shared 
view of the lifeworld of this kind of community (and its activism) is sustained by an interactive environment. The fact that such an environment remains highly reliant on online, third-party tools exposes the problematic relation with a technological infrastructure which instrumentalises, rather than nurtures, the communitarian aspect of online interaction. This means that arrangements pertaining to those memory-building online tools impact an essential aspect of the cohesiveness of the worldview of the online communities, namely, the permanence of shared knowledge and the value of the expressions of a worldview. The most evident example of such measures is the European Union Court of Justice's ruling acknowledging the role of OSPs in managing the 'right to be forgotten,' that is, the right to have search results and web contents removed when they collide with privacy (European Union Court of Justice, 2014; Travis and Arthur, 2014).

The social effects of online connectivity have become a "defining feature of the precariat" (Standing, 2011, p. 127). For Standing, this feature presents some threats to the affirmation of the class, which are related with the work/leisure balance in a context of instability and unpredictable schedule, further eroding the possibilities of association, identity creation, and political participation. In the PI case, connectivity, association, and identity building are brought together to strengthen the precariat as a presence in public life. By connecting the precariat worldview to the wider context of the Portuguese crisis, economic relations, and inequalities, the association addresses the status of a widening population group (Matos, 2012, p. 237 ff.).

One of the salient aspects of the case is the liability presented by the misuse of (in this case, Google Blogger's) reporting tools, or poor understanding of the nature of the weblog ecosystem on the part of the company and its representatives, disrupting the connection between the association and the precarious workers which it brings together. The fragility arising from technological dependence, however, would not suffice to endanger the civil liberties of the members of the community. It is only when understood in the context of legal systems, technological norms, and the collective practices or customs that the risk of a slippery slope starts to appear. It can take the shape of moral panic, of political convenience, but also of economic interest. Lacking the guise of outright censorship, the PI case shows a form of content control through the attempted suppression of the same discussion tool - weblog commenting - that is commonly used to engage in conversation and sharing experiences. However, this process can, in the instance of weblog comments, lead to the prosecution not only of the administrator of the weblog, but of the commenters themselves, thus discouraging potential participants.

\section{Concluding remarks}

This chapter has shown how communities, and in particular relatively marginal activist communities, may be affected in their task of memory building by sociotechnological arrangements allowing content removal or blocking. By drawing on studies of online 
communities and a phenomenology of technologically mediated memory-building, it analysed the social construction of community and memory, and potential chilling effects caused by content controls based on legal action against online activists. The analysis focused on a defamation case against a Portuguese online community and association of precarious workers in 2012 (Precários Inflexíveis). By using data from the Google Transparency reports to illustrate the use of defamation as rationale for content removal, this chapter points to the challenges to memory-building for online communities arising, on the one hand, from the activists' dependency on third party technology and applications and, on the other hand, from the specific laws and customs regarding their activity (specifically, defamation or libel laws).

Memory-building in cyberspace becomes more fragile under uncertain or insecure sociotechnological conditions. Vague or unfavourable legal frameworks for online expression, privacy, and data security, as well as dependence on service providers beholden to commercial and political interests, present serious challenges to the possibilities of speech and action of online activist communities. This raises much more alarming questions about user privacy, expectations of anonymity, and legal liability for opinions publicly expressed.

These findings suggest a need to reassess the sociotechnological and institutional frameworks of online activism. Communities woven into our fragmented globalized society require a set of conditions which includes technological mediation. Prospects for a strengthening of community cannot overlook the facts of contemporary life at the margins - connectivity without leisure, work without security, presence without sense of belonging. If community building and identity sharing move online to overcome these dilemmas, and in that process they become more exposed to the constraints of a shared sociotechnical system, aspects of the latter may and should be revised so as to not hinder the prospects of a more open and plural public life.

\section{References}

Abah, A.L. (2008), "Trends in International Internet Defamation Suits Targeting a Solution?", International Communication Gazette, Vol. 70 No. 6, pp. 529-546.

Barney, D. (2004), "The Vanishing Table, or Community in a world that is no world", in Feenberg, A. and Barney, D.D. (Eds.), Community in the digital age: Philosophy and practice, Rowman \& Littlefield, Lanham, Md., pp. 31-52.

Benkler, Y. (2006), The wealth of networks: How social production transforms markets and freedom, Yale Univ Pr., New Haven.

Bennett, W. (2003), "Communicating global activism", Information, Communication \& Society, Vol. 6 No. 2, pp. 143-168.

Berkley D. Sells. (2006), "Recent developments in internet defamation law", Journal of International Trade Law and Policy, Vol. 5 No. 1, pp. 1-17.

Castells, M. (2004), The power of identity, Wiley-Blackwell, Oxford. 
Castells, M. (2009a), Communication Power, Oxford University Press, Oxford.

Castells, M. (2009b), The Rise of the Network Society, Wiley-Blackwell, Oxford, $2^{\text {nd }}$ Ed., Vols. 1-3.

Chan, G.K. (2013), "Corporate defamation: reputation, rights and remedies", Legal Studies, Vol. 33 No. 2, pp. 264-288.

Coleman, S. (2004), The network-empowered citizen, Oxford Internet Institute, Oxford.

Costello, P.R. (2014), "Toward a phenomenology of community: Stein and Nancy", Emotion, Space and Society, doi:10.1016/j.emospa.2013.12.005.

Couldry, N. (2014), "The myth of 'us': digital networks, political change and the production of collectivity", Information, Communication \& Society, pp. 1-19.

Deibert, R.J. (2003), "Black Code: Censorship, Surveillance, and the Militarisation of Cyberspace”, Millennium-Journal of International Studies, Vol. 32 No. 3, pp. 501-530.

Deibert, R.J., Palfrey, J.G., Rohozinski, R. and Zittrain, J. (Eds.). (2008), Access Denied: The Practice and Policy of Global Internet Filtering, The MIT Press, Cambridge MA / London.

Deibert, R.J., Palfrey, J.G., Rohozinski, R. and Zittrain, J. (Eds.). (2010), Access Controlled: The Shaping of Power, Rights, and Rule in Cyberspace, The MIT Press, Cambridge MA / London.

DeNardis L. (2012), "Hidden levers of internet control: An infrastructure-based theory of Internet governance", Inf. Commun. Soc. Information Communication and Society, Vol. 15 No. 5, pp. 720-738.

Donk, W.B.H.J.V.D., Loader, B.D., Nixon, P.G. and Rucht, D. (Eds.). (2004), Cyberprotest: New Media, Citizens, and Social Movements, Routledge, London.

Dutton, W., Dopatka, A., Hills, M., Law, G. and Nash, V. (2011), Freedom of Connection-Freedom of Expression: The Changing Legal and Regulatory Ecology Shaping the Internet, Paris: UNESCO, available at: $\mathrm{http}: / /$ papers.ssrn.com/sol3/papers.cfm?abstract_id=1654464 (accessed 11 March 2013).

Dutton, W.H. (2013), "The Internet and Democrat Accountability: the rise of the fifth estate", in Lee, F.L.F., Leung, L., Qiu, J.L. and Chu, D.S.C. (Eds.),Frontiers in new media research, Routledge, New York, pp. 39-51.

Earl, J. and Kimport, K. (2011), Digitally enabled social change activism in the Internet age, MIT Press, Cambridge, Mass.

Elgesem, D. (2008), "Search engines and the public use of reason", Ethics and Information Technology, Vol. 10 No. 4, pp. 233-242.

Etzioni, A. (2004), "On virtual, democratic communities", in Feenberg, A. and Barney, D.D. (Eds.), Community in the digital age: Philosophy and practice, Rowman \& Littlefield, Lanham, Md., pp. 225-238.

European Digital Rights. (2012,November21), "Portuguese blog taken down by Google for unknown reasons", available at: http://www.edri.org/book/export/html/3142 (accessed 26 March 2013).

European Union Court of Justice. (2014, May13), “ARRÊT DE LA COUR (grande chambre) Dans l'affaire C- 131/12...”, available at: $\mathrm{http}$ //curia.europa.eu/juris/document/document_print.jsf?doclang=FR\&text=\&p ageIndex $=0 \&$ part $=1 \&$ mode $=1$ st $\&$ docid $=152065 \&$ occ $=$ first \&dir $=\& \operatorname{cid}=411047$ (accessed 28 November 2014).

Faria, N. (2012,May22), “Tribunal determina suspensão de comentários no blogue dos Precários Inflexíveis", Público Online, available at: http://www.publico.pt/n1547182 (accessed 26 March 2013). 
Feenberg, A. and Bakardjieva, M. (2004), "Consumers or citizens? The online community debate", in Feenberg, A. and Barney, D. (Eds.), Community in the digital age: Philosophy and practice, Rowman \& Littlefield, Lanham, Md., pp. $1-28$.

Feenberg, A. and Barney, D.D. (Eds.). (2004), Community in the digital age: Philosophy and practice, Rowman \& Littlefield, Lanham, Md.

Flichy, P. (2004), "L’individualisme connecté entre la technique numérique et la société", Réseaux, Vol. 124 No. 2, pp. 17-51.

Google (2014), "Google Transparency Report", available at: http://www.google.com/transparencyreport/ (accessed 28 November 2014).

Greenslade, R. (2014, October20), "23\% increase in defamation actions as social media claims rise", The Guardian, available at:

http://www.theguardian.com/media/greenslade/2014/oct/20/medialaw-socialmedia?CMP=twt_gu (accessed 20 October 2014).

Greenwald, G. (2014), No place to hide: Edward Snowden, the NSA, and the U.S. surveillance state, Metropolitan Books / Henry Holt, New York.

Gutman, Y., Adam D. Brown, and Amy Sodaro, eds. (2010), Memory and the Future: Transnational Politics, Ethics and Society, Palgrave MacMillan, London.

Hands, J. (2011), @ is for activism dissent, resistance and rebellion in a digital culture, Pluto, London; New York, NY.

Hick, S., Halpin, E.F. and Hoskins, E. (Eds.). (2000), Human Rights and the Internet, Macmillan Press, Basingstoke / London.

Hofmann, M., Reitman, R. and John, C. (2012), 2012: When the Government Comes Knocking, Who Has Your Back? - The Electronic Frontier Foundation's Second Annual Report on Online Service Providers' Privacy and Transparency Practices Regarding Government Access to User Data, Electronic Frontier Foundation, p. 15.

Hoskins, A. (2009), "The Mediatisation of Memory.” In Save As... Digital Memories, ed. Joanne Garde-Hansen, Andrew Hoskins, and Anna Reading, Palgrave Macmillan, London, pp.27-43.

Ihde, D. (1990), Technology and the Lifeworld: From Garden to Earth, Indiana University Press, Bloomington / Indianapolis.

- 2009. Postphenomenology and Technoscience: The Peking University Lectures. Albany: SUNY Press.

Introna, L.D. and Nissenbaum, H. (2000), "Shaping the Web: Why the Politics of Search Engines Matters", The Information Society, Vol. 16, pp. 169-185.

Joyce, M. (Ed.). (2010a), Digital activism decoded the new mechanics of change, International Debate Education Association, New York.

Joyce, M. (2010b), "Introduction: How to Think About Digital Activism", Digital activism decoded the new mechanics of change, International Debate Education Association, New York, pp. 1-14.

Kahn, R. and Kellner, D. (2004), "New Media and Internet Activism: From the 'Battle of Seattle' to Blogging”, New Media \& Society, Vol. 6 No. 1, pp. 87-95.

Karatzogianni, A. and Gak, M. (2015) "Hack or Be Hacked: The Quasi-Totalitarianism of Global Trusted Networks", New Formations, no. 84/85.

Klang, M. (2006), "Virtual Censorship: Controlling the Public Sphere”, in Berleur, J., Nurminen, M.I. and Impagliazzo, J. (Eds.),Social Informatics: An Information Society for all? In Remembrance of Rob Kling, IFIP International Federation for Information Processing, Springer US, pp. 185-194. 
Kohl, U. (2012), "The rise and rise of online intermediaries in the governance of the Internet and beyond - connectivity intermediaries", International Review of Law, Computers \& Technology, Vol. 26 No. 2-3, pp. 185-210.

Kohl, U. (2013), "Google: the rise and rise of online intermediaries in the governance of the Internet and beyond (Part 2)", International Journal of Law and Information Technology, Vol. 21 No. 2, pp. 187-234.

Liebman, J.M. (2006), "Defamed by a Blogger: Legal Protections, Self-Regulation and Other Failures", U. Ill. JL Tech. \& Pol'y, p. 343.

Martins, C.F. (2012,November15), "Blogue dos Precários Inflexíveis bloqueado desde quarta-feira", Público Online, available at: http://www.publico.pt/n1572616 (accessed 26 March 2013).

Matos, P. (2012), "Call center labor and the injured precariat: shame, stigma, and downward social mobility in contemporary Portugal", Dialectical Anthropology, Vol. 36 No. 3-4, pp. 217-243.

McCaughey, M. and Ayers, M.D. (Eds.). (2003), Cyberactivism: online activism in theory and practice, Routledge, New York.

Mendel, T. (2011), Mapping Digital Media: Online Media and Defamation, Reference Series, Cambridge: Open Society Foundation.

Mendel, T., Puddephatt, A., Wagner, B., Hawtin, D. and Torres, N. (2012), Global survey on internet privacy and freedom of expression, UNESCO series on internet freedom, Paris: UNESCO.

Nardi, B.A., Schiano, D.J., Gumbrecht, M. and Swartz, L. (2004), "Why we blog", Communications of the ACM, Vol. 47 No. 12, pp. 41-46.

Precários Inflexíveis. (2011, May 10), “Testemunho: AXES Market”, Precários Inflexiveis, available at:

http://www.precariosinflexiveis.org/2011/05/testemunho-axes-market.html (accessed 19 November 2012).

Precários Inflexíveis. (2012,December1), "Blog dos Precários Reabre - defenderemos sempre os trabalhadores e não aceitamos que nos censurem!", Precários Inflexiveis, available at: http://www.precariosinflexiveis.org/?p=4048 (accessed 26 March 2013).

Precários Inflexíveis. (2013, March 26), “Testemunhos", available at: http://www.precariosinflexiveis.org/?cat=13 (accessed 26 March 2013).

Precários Inflexíveis. (n.d.). "Estatutos da Associação de Combate à Precariedade Precários Inflexíveis", available at: https://doc-08-28docs.googleusercontent.com/docs/securesc/ha0ro937gcuc717deffksulhg5h7mbp 1/hu5o7d5vf3klcblii6uf3880cof7o73g/1416427200000/09708517329687333748 /*/0B4rUxvOVeEgxVzM0aTgyVHNKTG8?e=download (accessed 19 November 2014).

Reporters Without Borders. (2012), Internet Enemies Report 2012, Paris: Reporters Without Borders.

Reporters Without Borders. (2013), Enemies of the Internet 2013 Report - Special Edition: Surveillance, Paris: Reporters Without Borders.

Reporters Without Borders. (2014), Enemies of the Internet 2014 Report, Paris: Reporters Without Borders.

Salter, L. (2003), "Democracy, new social movements, and the Internet", Cyberactivism: Online activism in theory and practice, Routledge, New York / Abingdon, pp. 117-144. 
Soares, M. (2012, November 6), "Tribunal anula decisão de ocultar comentários no blogue dos Precários Inflexíveis", Público Online, available at: http://www.publico.pt/n1570325 (accessed 26 March 2013).

Standing, G. (2011), The Precariat: The New Dangerous Class, Bloomsbury Academic, London / New York.

Townend, J. (2014), "Online chilling effects in England and Wales | Internet Policy Review", Internet Policy Review, Vol. 3 No. 2, doi: 10.14763/2014.2.252.

Travis, A. and Arthur, C. (2014, May 13), "EU court backs 'right to be forgotten': Google must amend results on request", The Guardian, available at: http://www.theguardian.com/technology/2014/may/13/right-to-be-forgotten-eucourt-google-search-results (accessed 28 November 2014).

UNESCO. (2014), World trends in freedom of expression and media development, UNESCO, Paris.

Wellman, B., Quan-Haase, A., Boase, J., Chen, W., Hampton, K., de Diaz, I.I. and Miyata, K. (2003), "The social affordances of the Internet for networked individualism", Journal of Computer-Mediated Communication, Vol. 8 No. 3 , pp. $0-0$.

Zuckerman, E. (2010), "Intermediary Censorship", in Deibert, R.J., Palfrey, J., Rohozinski, R. and Zittrain, J. (Eds.), Access Controlled, The MIT Press, Cambridge MA / London, pp. 71-85.

Zuckerman, E., Roberts, H., McGrady, R. and Palfrey, J.G. (2010, December), "Distributed Denial of Service Attacks Against Independent Media and Human Rights Sites", The Berkman Center for Internet \& Society at Harvard University, available at: http://www.lateledipenelope.it/public/50facb14d2782.pdf (accessed 8 April 2013).

\section{Endnotes}

\footnotetext{
${ }^{i}$ Zuckerman et al. studied the use of distributed denial-of-service attacks against independent media and human rights websites, concluding that DDoS is but one of many forms of attacking and conditioning these communities (Zuckerman et al., 2010). ii 'Dislocation' here refers to the physical and symbolic distance between participants in an online community, both an obstacle to its overcoming of the reductionist effects of technological embodiment, and a constitutive element of the community's virtual body. iii The name of the association loosely translates as "Inflexible precarious workers," playing with the use of 'flexibility' understood as adaptability to the dominant work conditions.

iv Specifically, Law 1/99, known as "Journalists' Statute" and Law 2/99, known as "Press Law", which regulates professional media.

${ }^{v}$ Specifically, articles 180 and following of the Criminal Code (Código Penal), art. 484 of the Civil Code, and article 26 of the Constitution of the Portuguese Republic. ${ }^{v i} \mathrm{Cf}$. article 184 of the Criminal Code.

vii Google Transparency Report (Google, 2014), and Google (corporation) have been praised for its commitment for transparency by the Electronic Frontier Foundation in a report concerning online companies' privacy and transparency practices vis-à-vis government requests (Hofmann et al., 2012). The company is also involved with the Global Network Initiative (GNI), along with other companies and civil society groups.
} 
The goals of GNI are linked to the promotion of international standards for the protection of user's rights and privacy online, particularly regarding governmental requests.

viii Note that link removal requests are not included in the data shown in this chapter. Copyright holders' requests for Google to remove non-authorised links from its search results are extremely numerous. Data may be found in the relevant GTR webpage (http://www.google.com/transparencyreport/removals/copyright/).

${ }^{\text {ix }}$ Other intermediary companies, such as national/ local ISPs (internet service providers), are more exposed to "regulatory coercion", and less likely to jeopardize operating licenses (Mendel et al., 2012, p. 28). 